\title{
REFERENCES
}

BerThold, P. 1975. Der Seidenschwanz Bombycilla garrulus als frugivorer Ernährungsspezialist. Experientia 32: 1445 .

Berthold, P. 1976. Animalische und vegetabilische Ernährung omnivorer Singvogelarten: Nahrungsbevorzugung, Jahresperiodik der Nahrungswahl, physiologische und ökologische Bedeutung. J. Ornithol. 117: 145-209.

Herrera, C. M. In press. Fruit food of Robins wintering in southern Spanish mediterranean scrubland. Bird Study.

Herrera, C. M. \& Jordano, P. 1981. In press. Prunus mahaleb and birds: the high-efficiency seed dispersal system of a temperate fruiting tree. Ecol. Monog. 51.

JoRDANo, P. 1979. Estrategias reproductivas de las zarzas (Rubus ulmifolius, Rosaceae): coevolución con los pájaros dispersantes de las semillas. Tesis Licenc., Univ. Córdoba.

Klein, H., Berthold, P. \& Gwinner, E. 1973, Der Zug europäischer Garten- und Mönchsgrasmücken (Sylvia borin und S. atricapilla). Vogelwarte 27: 73-134.

Langslow, D. R. 1979. Movements of Blackcaps ringed in Britain and Ireland. Bird Study 26: 239-252.

MCAtEe, W. L. 1947. Distribution of seeds by birds. Am. Midl. Nat, 38: 214-223.

McKey, D. 1975. The ecology of coevolved seed dispersal systems. In Gilbert, L. E. and Raven, P. H. (eds.), Coevolution of animals and plants: 159-191. Austin: Univ. Texas Press.

Moony, D. T. 1970. A method for obtaining food samples from insectivorous birds. Auk 87: 579.

Murillo, F. \& Sancho, F. 1969. Migración de Sylvia atricapilla y Erithacus rubecula en Doñana según datos de capturas. Ardeola 13: 129-137.

SNow, D. W. 1971. Evolutionary aspects of fruit-eating by birds. Ibis 113: 194-202.

Turcek, F. J. 1961. Ökologische Beziehungen der Vögel und Gehölze. Bratislava: Verlag Slowakischen Akademie der Wissenschaften.

TutmaN, I. 1969. Beobachtungen an olivenfressenden Vögeln. Vogelwelt 90: 1-8.

Walsberg, G. E. 1975. Digestive adaptations of Phainopepla nitens associated with the eating of mistletoe berries. Condor 77: 169-174.

Walsberg, G. E. 1977. Ecology and energetics of contrasting social systems in Phainopepla nitens (Aves: Ptilogonatidae). Univ. Calif. Publ. Zool. 108: 1-63.

Estación Biológica de Doñana, Sevilla-12, Spain

\section{PERSISTENCE OF LOCAL WINGFLAP DIALECTS IN FLAPPET LARKS MIRAFRA RUFOCINNAMOMEA}

\author{
ROBERT B. PAYNE \\ Received 21 May 1980
}

Local geographic variation of song has been described for many songbirds but information on the long-term persistence of local song differences is sparse. If song dialects persist over many generations, they may have evolutionary significance (Armstrong 1963, Thielcke 1970). Reports of local dialect differences persisting over several generations of birds are not generally documented with audiospectrograms (Armstrong 1963). Local songs have been known for decades in coastal central California in the White-crowned Sparrow Zonotrichia leucophrys. Songs in two areas (Berkeley, Tilden Park) have persisted across at least ten years [compare audiospectrograms in Marler \& Tamura (1962) and Baptista (1975)]. Songs were also described by diagrammatic field sketches by Blanchard (1941) and Peterson (1941) in the 1930s and four of these local 'song communities' were similar to the local songs recorded in the 1960s (Marler \& Tamura 1962, Baptista 1975). The pattern similarities suggest long-term song continuity but the early field sketches were necessarily less detailed and accurate than the later audiospectrograms and it is impossible to test the details of local song continuity from these data. Moreover there is no evidence of the stability of the microgeographic boundary of the song populations over more than a single generation. The boundary between the Berkeley and Tilden Park dialects has broken down over three years with a shift and an overlap in the local distribution of the songs (Baptista 1975: 61). On Point Reyes, Baker found a sharp 
boundary line between two neighbouring song populations and reported on certain isozyme morphs (Baker 1975) and the tendency of birds not to disperse from one neighbourhood to another (Baker \& Mewaldt 1978). Although the dispersal study spanned several years, songs were reported for only 1972 and 1973 and we have no evidence available to test whether the local songs or the boundary between them have remained stable across several generations.

Chaffinch Fringilla coelebs populations on the other hand had different song types after several years (Slater \& Ince 1979) but local song variation in the Chaffinch is complex and is not clearly dialectal (Pickstock, Krebs \& Bradbury 1980). Local songs persist at least a few years in the Splendid Sunbird Nectarinia coccinigaster but again song variation in this species is not distinctly dialectal (Payne 1978a). In some songbird species local dialects have developed within a few generations (Mundinger 1976). I know of no reports for any species where local song differences have persisted between neighbouring populations in which the dialect boundaries have remained stable over a period of years.

The wingflaps of the African Flappet Lark Mirafra rufocinnamomea are similar to song in their function in territorial advertisement and their very local distribution is like that of dialects of vocal song (Wickler 1967, Payne 1973, 1978b, Seibt 1975, Bertram 1977). The larks are common at Lochinvar National Park, Zambia, where two main dialect groups were recorded in 1973 and 1974 (Payne 1978b). The park was visited again in 1979 to compare the local wingflap dialect with those of the earlier sample. Daily field work from 24 February to 17 April resulted in observations and tape recordings of 22 individual larks and observations of seven additional birds, all between 25 February and 23 March. From one to 18 wingflap displays for each bird were recorded at $9.5 \mathrm{~cm} \mathrm{~s}^{-1}$ using a Uher 4000-IC tape recorder and M-517 microphone in a parabolic reflector and the longest wingflap display for each bird was audiospectrographed with a Kay 3090-A Vibralyzer using the wide-band filter. Individuals varied in the number of wingflap bursts (two or three) in a display, in the number of notes in the burst and in the interval between bursts (Fig. 1). Intra-individual variation was found only in the long final burst of wingflap with one or two individual notes fewer in the shortest songs (two birds). Individuals were distinguished by location (more than $500 \mathrm{~m}$ from the nearest other wingflap heard or recorded), by continuing observation during a series of wingflap displays and in the case of neighbouring birds by watching and hearing all birds simultaneously and by identifying each wingflap display by my voice, as the display was tape recorded.

Local wingflap dialects were evident in 1979 (Figs 1 and 2). Birds in the east of the park had three bursts in each wingflap display, while birds in the west had two bursts. Seven additional birds were heard but not taped. One had a two-burst display $2.5 \mathrm{~km} \mathrm{E}$ of W3, two had three-burst displays between $\mathrm{O} 1$ and the park boundary and four had three-burst displays $1 \mathrm{~km} \mathrm{~N}$ of M1, $2 \mathrm{~km} \mathrm{NW}$ of N5, $400 \mathrm{~m} \mathrm{NW}$ of P1 and $200 \mathrm{~m} \mathrm{~N}$ of N3. However, two birds recorded in the centre of the study area (P5, P6) had two-burst displays rather than the three-burst displays of the other birds taped or heard within $2 \mathrm{~km}$ of this site. The two each gave at least eight successive wingflap displays with no evident variation. Within each of the two major dialect areas, neighbouring birds generally had flaps more similar to each other than to more remote birds: M1-M2, M3-M4, N1-N2 (but not N3), P3-P4, P5-P6 and W4-W5 (Fig. 1).

In 1973-74 the lark population consisted of a three-phrase wingflap dialect in the east and a two-phrase dialect in the west, with the same dividing line between the dialect areas as in 1979, except for birds P5 and P6. The microgeographic pattern of local wingflap dialects persisted over five years. The population biology of Flappet Larks is not known and I know of no ringing studies to determine local dispersal or survival. Annual mortality of adult larks of another species, the Skylark Alauda arvensis in Britain, is $33.5 \%$ (Delius 1965). Other small ground-feeding birds of open woodland in southern 


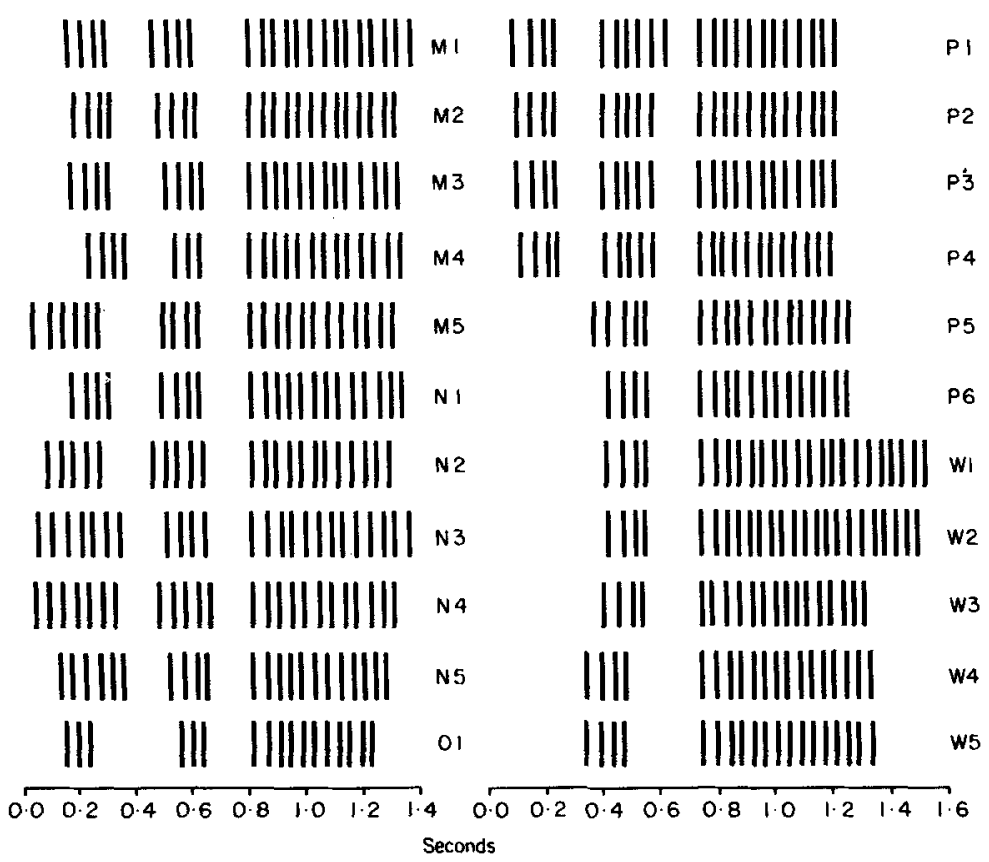

Figure 1. Wingflap displays of 22 Flappet Larks at Lochinvar National Park, Zambia, in 1979. The temporal patterns of display were traced from audiospectrograms.

Africa have an even higher annual mortality rate (Payne \& Payne 1977) and the rate may be close to that of the Flappet Larks in Zambia. The number of surviving members of the original adult population in later years is described by the expression $n=B \mathrm{e}^{-k t}$, where $B$ is the original number, $\mathrm{e}$ is the base of natural logarithms, $k$ is the annual mortality rate and $t$ is the number of years. With an annual mortality rate of 0.335 the half-life of an adult population cohort would be 2.05 years and the local adult lark population would replace itself about twice during a five-year interval. It seems likely that the local distribution of wingflap dialects have persisted over a few generations of Flappet Larks at Lochinvar Park.

Although wingflap dialects persisted in the same local areas, there is no reason to suspect that the populations are genetically differentiated or that they would become distinct with time. Bird K of 1973 (a three-flap lark) was only $400 \mathrm{~m}$ from an unrecorded two-flap lark of 1979 and birds P5 and P6 shared the two-burst wingflap with the western birds though their neighbours had a three-burst wingflap. These observations suggest dispersal and they indicate no behavioural isolation between the two dialect populations. Also from field observations, aerial photographs (Payne 1978b) and the vegetation (Douthwaite \& Van Lavieren 1977, unpublished map) there are no habitat barriers to dispersal between the two dialect areas. The vegetation has changed progressively and drastically with increasing use by cattle and woodcutting. Due mainly to annual fires only one species of tree has reproduced successfully within more than 15 years but these changes have occurred throughout the park and have not been accompanied by shifts of the dialect areas. The persistence of local wingflap dialects and the closest match between neighbouring birds are consistent with the hypotheses that birds copy the wingflap display from their neighbour, perhaps after dispersal from the birth site, and that the imitation may be advantageous in territorial advertisement when the mimics establish and maintain their territory (Payne 1978b). 


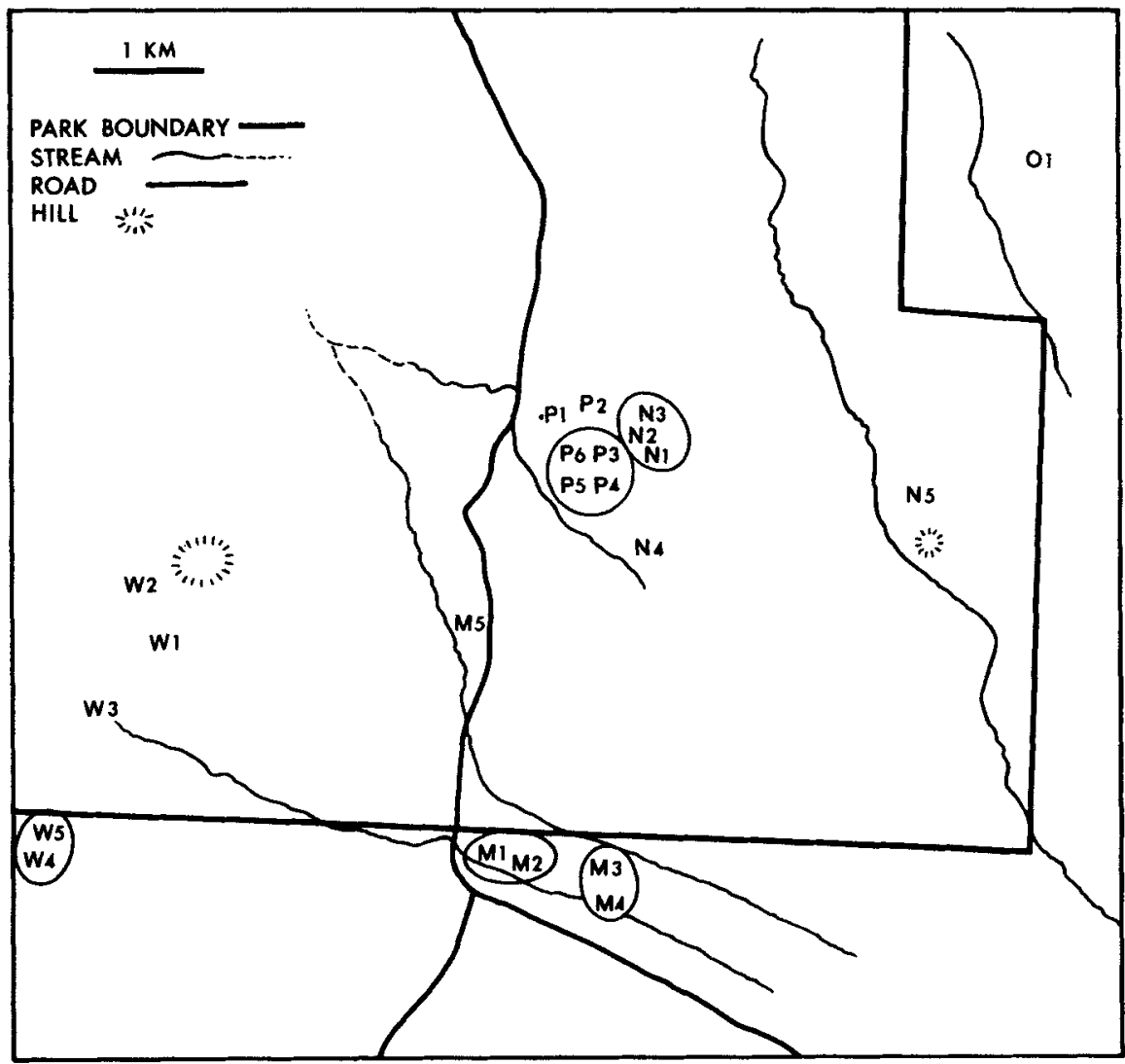

Figure 2. Map of the southern portion of Lochinvar National Park, Zambia, and neighbouring village areas. Locations of 22 Flappet Larks recorded in 1979 are indicated by the letters. Birds that were recorded within $200 \mathrm{~m}$ of the observer at the same time and that were determined to be distinct individuals are circled.

I am grateful to the National Parks and Wildlife Service, Zambia, for permission to study birds at Lochinvar and for accommodations. Field work was supported by the National Science Foundation.

\section{REFERENCES}

Armstrong, E. A. 1963. A study of bird song. London: Oxford University Press.

BAKER, M. C. 1975. Song dialects and genetic differences in White-crowned Sparrows (Zonotrichia leucophrys). Evolution 29: 226-241.

Baker, M. C. \& Mewaldt, L. R. 1978. Song dialects as barriers to dispersal in White-crowned Sparrows, Zonotrichia leucophrys nuttalli. Evolution 32: 712-722.

Baptista, L. F. 1975. Song dialects and demes in sedentary populations of the White-crowned Sparrow (Zonotrichia leucophrys muttalli). Univ. Calif. Publ. Zool. 105: 1-78.

Bertram, B. C. R. 1977. Variation in the wing-song of the Flappet Lark. Anim. Behav. 25: 165-170.

Blanchard, B. D. 1941. The White-crowned Sparrows (Zonotrichia leucophrys) of the Pacific seaboard: environment and annual cycle. Univ. Calif. Publ. Zool. 46: 1-178.

Delrus, J. D. 1965. A population study of Skylarks Alauda arvensis. Ibis 107: 466-492.

Douthwaite, R. J. \& Van LAvieren, L. P. 1977. A description of the vegetation of Lochinvar National Park Zambia. Nat. Council Sci. Res., Lusaka, Zambia, Tech. Rep. 34.

Marler, P. \& TAmura, M. 1962. Song 'dialects' in three populations of White-crowned Sparrows. Condor 64: 368-377.

Mundinger, P. 1976. Song dialects and colonization in the House Finch, Carpodacus mexicamus, on the east coast. Condor $77 ; 407-422$.

PAYNE, R. B. 1973. Wingflap dialects in the Flappet Lark Mirafra rufocinnamomea. Ibis 115: 270-274.

PAYNE, R. B., 1978a. Microgeographic variation in songs of Splendid Sunbirds Nectarinia coccinigaster: population phenetics, habitats and song dialects. Behaviour $65: 282-308$. 
Payne, R. B. 1978b. Local dialects in the wingflaps of Flappet Larks Mirafra rufocinnamomea. Ibis 120: 204-207.

PAYNe, R. B. \& PAYNe, K. 1977. Social organization and mating success in local song populations of Village Indigobirds, Vidua chalybeata. Z. Tierpsychol. 45: 113-173.

Peterson, R. T. 1941. A field guide to western birds. Boston: Houghton Mifflin.

Pickstock, J. C., Krebs, J. R. \& Bradbury, S. 1980. Quantitative comparison of sonagrams using an automatic image analyser: application to song dialects of Chaffinches Fringilla coelebs. Ibis 122: 103-109.

SEIbT, U. 1975. Instrumentaldialekte der Klapperlerche Mirafra rufocinnamomea (Salvadori). J. Ornithol. 116: 103-107.

Slater, P. J. B. \& INCE, S. A. 1979. Cultural evolution in Chaffinch song. Behaviour 71: 146-166.

Thielcke, G. 1970. Lernen von Gesang als möglicher Schrittmacher der Evolution. Z. Zool. Syst. Evol. 8: 309-320.

WiCKLlER, W. 1967. Der 'Flügelsang' der ostafrikanischen Klapperlerche Mirafra rufocinnamomea (Salvadori). Vogelwelt 88: 161-165.

Museum of Zoology and Division of Biological Sciences, The University of Michigan, Ann Arbor, Michigan 48109, U.S.A.

\title{
GONADAL CONDITION OF NON-BREEDING WHL AND DOMESTICATED BUDGERIGARS MELOPSITTACUS UNDULATUS
}

\author{
Edmund Wyndham, Rosemary E. Hutchison \& Barbara F. Brockway-Fuller
}

Received 28 May 1980

Budgerigars Melopsittacus undulatus are small parrots $(c .29 \mathrm{~g})$ that inhabit the semiarid and arid interior of Australia. Throughout the year, when breeding and not breeding, they occur in large heterosexual flocks (Wyndham 1980a) and feed on small seeds produced by a variety of grasses and small shrubs (Wyndham 1980b). Notes from naturalists suggest the timing of breeding is highly variable and can be continuous while favourable conditions prevail (Grould 1865, Broinowski 1890, Cayley 1933, Serventy \& Whittell 1962, Serventy 1971). In a study of the Budgerigar in eastern Australia, Wyndham (1978, in press) found that, while the timing of breeding was variable, there was an underlying seasonality. In the south Budgerigars usually bred in spring, in mid-latitudes in the hot months (October to March) and in the north in the winter. In mid-latitudes when Budgerigars were not breeding the gonads regressed and this regression occurred while Budgerigars were in heterosexual flocks and natural nesting sites (hollows in trees) were available.

Domesticated Budgerigars breed readily in captivity. When caged as heterosexual pairs that are able to see and hear other pairs and are supplied with nest-boxes and water $a d$ libitum, Budgerigars maintain active gonads (Ficken et al. 1960, Brockway 1964a, Hutchison 1974). The testes of paired males regress if they are visually or vocally isolated from other pairs (Ficken et al. 1960, Borckway 1964b) and females do not ovulate if they cannot enter nest-boxes (Hutchison 1974) or cannot hear male vocalizations (Brockway 1962, 1965). Thus gonadal regression in caged, domesticated Budgerigars occurs only under experimental conditions that are unlikely to occur for wild birds. This paper compares the extent of gonadal regression in domesticated Budgerigars when deprived of certain external stimuli and in wild Budgerigars that are not breeding.

\section{SOURCES OF DATA}

Wild birds with regressed gonads were collected by Wyndham from locations shown in Table 1. These birds were from populations of several hundred to a few thousand birds of mixed sexes. The birds had ready access to water in man-made ground tanks and bore drains and had access to nest-holes that were in hollow limbs of trees. Flocks from which the samples WA, WB and WC were taken contained no juveniles and no courtship or nest-hole orientated behaviour by individuals was seen, which suggests they 